\title{
KAZIMIERZA AJDUKIEWICZA ANALIZA SYNTAKTYCZNA A PROBLEM WYRAŻEŃ NIEPEŁNYCH
}

\begin{abstract}
KAZIMIERZ AJDUKIEWICZ's SyNTACTIC ANALYSIS AND THE PROBLEM OF INCOMPLETE EXPRESSIONS This paper discusses the problem of applying Kazimierz Ajdukiewicz's method of syntactic analysis to incomplete expressions that occur in natural languages. The author defends the claim that it is impossible effectively to apply syntactic analysis to any expressions of natural languages, due to the presence of incomplete expressions. First, the author outlines the basic concepts and describes Ajdukiewicz's selected views on incomplete expressions, as well as his method of syntactic analysis. Second, using the example of various types of incomplete expressions, the author presents problems that arise when syntactic analysis is applied to expressions of natural languages.

Keywords: Kazimierz Ajdukiewicz, syntactic analysis, incomplete expressions, natural language, ellipsis
\end{abstract}

W 1935 roku Kazimierz Ajdukiewicz, zainspirowany poglądami Edmunda Husserla i Stanisława Leśniewskiego, przedstawił metodę analizy syntaktycznej wyrażeń. W swojej pracy pisze, że jednym z najbardziej doniosłych zadań logiki jest badanie sensowności wyrażeń. Dotyczy to zarówno symbolicznych języków formalnych, jak i języków naturalnych. W związku z tym rozważa następujący problem: jakie warunki muszą być spełnione, aby pewien ciąg sensownych wyrazów mial jednolity sens? Odpowiedzią na to pytanie ma być właśnie jego metoda, u podstaw której leży założenie, że każde wyrażenie spójne syntaktycznie jest sensowne (Ajdukiewicz 1935: 1-3).

$\mathrm{W}$ językach naturalnych powszechnym zjawiskiem jest występowanie wyrażeń zawierających pewne braki składniowe. Zastosowanie do tych wyrażeń

* Katedra Logiki, Uniwersytet Mikołaja Kopernika w Toruniu, ul. S. Moniuszki 16/20, 87-100 Torun, e-mail: patrycjusz220@gmail.com, ORCID: https://orcid.org/oooo-o0o22212-3381. 
metody Ajdukiewicza nastręcza wielu trudności, o czym można się przekonać, sprawdzając ich poprawność. Mieszko Tałasiewicz (2001: 69), badając problemy metody Ajdukiewicza, porusza wątek zastosowania analizy do wyrażeń niepełnych i rozważa dwa podejścia: można albo (1) trzymać się ściśle metody Ajdukiewicza i uznać, że wszystkie wyrażenia niepełne są błędne, albo (2) podać wyrażenie treściowo tożsame, a dopiero potem przeprowadzić analizę syntaktyczną. Tałasiewicz przedstawia zarzuty wobec obu podejść, chociaż nie podaje żadnego rozwiązania. Jak słusznie zauważa, w przypadku (1) należałoby uznać wiele intuicyjnie sensownych wyrażeń niepełnych za bezsensowne. Z kolei podejście (2) stawia logika przed koniecznością sięgnięcia o wiele dalej niż do samej metody.

Problem wyrażeń niepełnych jest dla Tałasiewicza (2001: 74-75) jednym z argumentów potwierdzających nieefektywność analizy syntaktycznej Ajdukiewicza. W tej pracy stawiam mocniejszą tezę: istnienie wyrażeń niepełnych w językach naturalnych sprawia, że nie można rozstrzygać o sensowności żadnych wyrażeń języków naturalnych za pomocą metody analizy syntaktycznej Ajdukiewicza. Zagadnienie wadliwości analizy syntaktycznej sprowadzam zatem do problemu wyrażeń niepełnych jako wystarczających, aby całkowicie - zważywszy na ich nagromadzenie w języku naturalnym - podważyć zasadność analizy syntaktycznej jako narzędzia sprawdzania sensu. Pozostałe trudności pominę, ponieważ są dostatecznie opisane w literaturze przedmiotu.

Praca składa się z trzech części. W pierwszej omawiam zagadnienie wyrażenia eliptycznego i niedopowiedzenia oraz metodę analizy syntaktycznej. W drugiej badam, co sam Ajdukiewicz ma do powiedzenia w kwestii wyrażeń niepełnych. W ostatniej części przedstawiam argumentację na rzecz postawionej w tej pracy tezy.

\section{POJĘCIA WSTĘPNE}

\subsection{WYRAŻENIA NIEPEŁNE}

O wyrażeniach ${ }^{1}$ niepełnych można powiedzieć, że są one nieodłączną częścią naturalnej komunikacji - zjawiskiem regularnym, a nie wyjątkowym. Jesteśmy do tego stopnia przyzwyczajeni do wyrażeń niepełnych, że nawet nie odróżniamy ich od wyrażeń pełnych, nie budzą w nas żadnego zdziwienia.

\footnotetext{
${ }^{1}$ Przez „wyrażenia” rozumiem wyrażenia języka naturalnego w użyciu komunikacyjnym, a zatem wyrażenia jako wypowiedzi językowe. W związku z tym określeń „wyrażenie”, „wyrażenie języka naturalnego” i „wypowiedź” używam zamiennie.
} 
Dopiero naukowy namysł pozwala na uchwycenie niezwykłości, która się za nimi kryje. Najczęściej pojawiającym się wyrażeniem niepełnym jest wyrażenie eliptyczne ${ }^{2}$.

\section{DEFINICJA 1.1. WYRAŻENIE ELIPTYCZNE}

Wyrażenie eliptyczne to wyrażenie złożone, w którym brakuje jakiegoś wyrażenia składowego, ale mimo to można zrozumieć sens całego wyrażenia 3 .

Obok wyrażeń eliptycznych $\mathrm{w}$ językach naturalnych występują niedopowiedzenia. Mamy z nimi do czynienia wtedy, gdy w żaden sposób wypowiedź nie może być zrozumiana przez odbiorcę. Zdarza się tak na przykład w wyrażeniach typu: „Ludzie są beznadziejni”. Brak kwantyfikatora często sprawia, że odbiorca nie jest w stanie określić, ilu albo jakich ludzi nadawca ma na myśli. Wtedy takie wyrażenie jest bezsensowne ze względu na to, że mimo iż potencjalnie może przyjąć wiele znaczeń, to $\mathrm{w}$ momencie jego użycia nie można wskazać żadnego. Innymi słowy, nie istnieje taki kontekst, który pozwalałby na wybranie jednego spośród wielu możliwych znaczeń.

\section{DEFINICJA 1.2. NIEDOPOWIEDZENIE}

Niedopowiedzenie to wyrażenie złożone, w którym brakuje jakiegoś wyrażenia składowego, na tyle istotnego, że bez niego całe wyrażenie nie może być zrozumiane 4 .

\subsection{METODA AJDUKIEWICZA}

Przybliżywszy pojęcia wyrażenia eliptycznego i niedopowiedzenia, przejdźmy do Ajdukiewicza. W swojej pracy $O$ spójności syntaktycznej proponuje metodę, która ma pozwolić na zbadanie, czy dane wyrażenia złożone mają sens w jakimś

${ }^{2}$ Przyjęte tutaj definicje wyrażenia eliptycznego i niedopowiedzenia oczywiście mogą podlegać dyskusji. Mają one jednak charakter roboczy, chodzi głównie o odróżnienie takich wyrażeń niepełnych, które są zrozumiałe, od takich, które nie są zrozumiałe. Celowo też nie podaję tutaj jakichś ścisłych kryteriów odróżniania niedopowiedzeń od wyrażeń eliptycznych, ponieważ może zdarzyć się tak, że w pewnych sytuacjach ten sam brak składniowy powoduje niemożność zrozumienia wypowiedzi (a zatem wyrażenie ma charakter niedopowiedzenia), a w innych jest domyślny (a zatem ma charakter eliptyczny).

3 Podobnie, chociaż nie wprost, definiuje wyrażenia eliptyczne Grochowski (1976: 121130). Podobną definicję znajdujemy też w słowniku Kopalińskiego (2007: 160), gdzie dowiadujemy się, że „elipsa to opuszczenie w zdaniu wyrazów, których można się domyślić”. Wyrażenie eliptyczne nazywa się również „wyrażeniem z wyrzutnią”, a samo opuszczenie domyślnego składnika wyrażenia nazywa się wyrażeniem eliptycznym czy też wyrzutnią.

4 Jest to parafraza poglądów Pelca (1971: 61) na temat tego, czym jest niedopowiedzenie. 
języku. Przyjmuje explicite twierdzenie, że wyrażenie jest zbudowane zgodnie z regułami syntaktycznymi (inaczej: spójne syntaktycznie) wtedy i tylko wtedy, gdy jest wyrażeniem sensownym języka. $Z$ tego wynika, że jeżeli wyrażenie jest niespójne syntaktycznie, to jest pozbawione w tym języku jednolitego znaczenia. Dlatego też Ajdukiewicz (1985a: 222) uważa, że jednym z najdonioślejszych zadań logiki jest podanie warunków, przy których wyrażenie można uznać za spójne syntaktycznie, czyli inaczej mówiąc, zbudowane zgodnie z regułami syntaktycznymi. Dysponując zbiorem takich warunków, bylibyśmy w stanie ustalać, czy pewne wyrażenia są sensowne czy nie. Żeby w pełni przedstawić swoją metodę, wprowadza najpierw za Leśniewskim pojęcie kategorii syntaktycznej.

\section{DEFINICJA 1.3. KATEGORIA SYNTAKTYCZNA}

Wyrażenie $w_{1}$, wzięte $\mathrm{w}$ znaczeniu $x$, i wyrażenie $w_{2}$, wzięte $\mathrm{w}$ znaczeniu $y$, należą do tej samej kategorii syntaktycznej wtedy i tylko wtedy, gdy istnieje takie zdanie $w_{3}$, w którym $w_{1}$ występuje w znaczeniu $x$ i które po zastąpieniu jego składnika $w_{1}$ przez wyrażenie $w_{2}$ wzięte w znaczeniu $y$, przy ścisłym zachowaniu znaczenia pozostałych słów i składni zdania $w_{3}$, przekształca się $\mathrm{w}$ wyrażenie $w_{4}$, które jest również zdaniem (Ajdukiewicz 1985a: 223).

Na przykład, gdy w zdaniu „Ala ma kota” w miejsce „Ala” wstawimy „pies jedzie koleją", w rezultacie otrzymamy konstrukcję „pies jedzie koleją ma kota”. Nie jest ona zdaniem, ponieważ nie spełnia polskich reguł syntaktycznych. Znaczy to, że wyrażenia „Ala” i „pies jedzie koleją” nie należą do tej samej kategorii syntaktycznej. Z kolei, gdy w miejsce „Ala” wstawimy „pies”, w rezultacie mamy zdanie „pies ma kota”, a zatem „Ala” i „pies” to wyrażenia należące do tej samej kategorii. Ten przykład bardzo dobrze ilustruje, na czym polega przynależność dwóch wyrażeń do tej samej kategorii syntaktycznej5. Nie wyjaśnia jednak, z jakimi kategoriami ma do czynienia przeciętny użytkownik języka.

Podstawowymi kategoriami są kategoria zdaniowa (zdania w sensie logicznym) i kategoria nazwowa (nazwy). Obok kategorii zdaniowej i nazwowej występują również kategorie funktorowe. Zauważmy, że w przypadku tych dwóch pierwszych mowa jest o pojedynczych kategoriach syntaktycznych. W tym sensie jest tylko jedna kategoria nazwowa, dowolna nazwa, niezależnie od swojej złożoności, wymienia się z dowolną inną nazwą. Tak samo jest w przypadku kategorii zdaniowej. Funktory natomiast jako takie nie tworzą jednej kategorii

\footnotetext{
5 Warto tutaj dodać, że Ajdukiewicz posługuje się jeszcze innymi określeniami, takimi jak „kategorie znaczeniowe” albo „kategorie semantyczne”. W tej pracy będę posługiwać się określeniem „kategorie syntaktyczne”.
} 
syntaktycznej, nie można więc mówić o „kategorii funktorowej”, lecz o „kategoriach funktorowych" (Ajdukiewicz 1985a: 224). Jednak, mimo że nie możemy podać definicji kategorii funktorowej, potrafimy wyjaśnić, czym jest funktor.

\section{DEFINICJA 1.4. FUNKTOR}

Funktor to wyrażenie, które wiąże wyrażenia w wyrażenia bardziej złożone lub modyfikuje obecny już funktor 6 .

Ajdukiewicz stwierdza, że w odróżnieniu od nazw i zdań, funktory pełnią rolę aktywną - tworza wyrażenie. Możemy je zatem porównać do znaku funkcyjnego w matematyce. Same niczego nie znaczą, lecz nabierają znaczenia dopiero w połączeniu z innymi wyrażeniami (Ajdukiewicz 1994: 164-165). Jeżeli natomiast chodzi o ich odmiany, to możemy wyróżnić trzy typy: zdaniotwórcze (tworzą zdania), nazwotwórcze (tworzą nazwy złożone) i funktorotwórcze (modyfikują inne funktory) ${ }^{7}$.

Ze zdaniami ściśle związane są funktory główne, czyli takie, które spajają całe zdanie. W przypadku zdań prostych wskazanie takiego funktora nie jest trudne, ponieważ występuje w nich tylko jeden funktor zdaniotwórczy: na przykład w zdaniu „Ala ma kota” jest to niewątpliwie wyraz „ma”. W zdaniach złożonych sprawa się komplikuje, ponieważ mamy w nich do czynienia z wieloma funktorami. Wśród nich są takie, które spajają wewnętrznie zdania składowe (są ich funktorami głównymi), a także funktor, który łączy te zdania w jedną całość. To właśnie ten jeden funktor jest funktorem głównym całego zdania złożonego.

\section{DEFINICJA 1.5. FUNKTOR GŁÓWNY}

Wyrażenie spójne syntaktycznie można podzielić na części składowe w taki sposób, że jedno wyrażenie będzie funktorem, a pozostałe wyrażenia składowe jego argumentami. Ten funktor jest funktorem głównym wyrażenia (Ajdukiewicz 1993: 168).

Weźmy na przykład takie zdanie złożone: „Ala ma kota oraz Jan udał się na wycieczkę”. Rozpoznajemy tu trzy funktory: „ma”, „oraz”, „udał się”. Funktor „ma” spaja zdanie proste, którym jest „Ala ma kota”, a funktor „udał się” two-

${ }^{6}$ Ajdukiewicz nie podaje wprost definicji funktora, lecz przeglądając jego omówienie funktorów (Ajdukiewicz 1993: 167-168), widzimy, że funktor albo wiąże wyrażenia w wyrażenia bardziej złożone, albo modyfikuje obecny już funktor.

7 Te typy również nie tworzą kategorii syntaktycznych: nie jest tak, że funktory należące do jednego typu wymieniają się ze sobą w dowolnym kontekście. Jednak rozważania nad problemem, kiedy funktory należą do jednej kategorii syntaktycznej, zostaną tutaj pominięte, ponieważ nie dotyczą przedmiotu pracy. Wspominam tutaj o tym głównie w celu zachowania przejrzystości myśli i uniknięcia nieporozumień. 
rzy zdanie proste, którym jest „Jan udał się na wycieczkę”. Te dwa funktory są funktorami głównymi tych zdań prostych, natomiast funktorem głównym całego zdania złożonego okazuje się spójnik „oraz”, który łączy te dwa zdania proste w jedno zdanie złożone. Bez niego nie byłoby tego zdania jako całości.

Mając ogólne rozeznanie w kategoriach syntaktycznych, wprowadźmy teraz pojęcie indeksu Ajdukiewicza, a następnie przyjrzyjmy się procedurze analizy syntaktycznej i warunkom spójności wyrażenia.

\subsubsection{INDEKS AJDUKIEWICZA}

Indeks Ajdukiewicza to sposób oznaczania wyrażeń ze względu na to, do jakiej kategorii syntaktycznej należą. Są dwie kategorie podstawowe, które pełnią bierną rolę: nazwy i zdania. Będą one kolejno za Ajdukiewiczem (1993: 167) oznaczane jako wskaźniki $n$ i z. Funktory zaś pełnią rolę aktywną, a więc budują wyrażenia. Nie należą do jednej kategorii syntaktycznej, zatem nie możemy podać stałego oznaczenia, które mogłoby wskazywać ich wzajemną wymienialność. Zależnie od tego, jakie wyrażenia tworzą, będziemy je różnie zapisywać. Można jednak podać ogólny schemat oznaczania funktorów, który wygląda następująco:

$$
\frac{\alpha}{\beta_{1}, \beta_{2}, \ldots, \beta_{n}}
$$

gdzie $\alpha$ oznacza wyrażenie, które funktor tworzy z argumentów $\beta_{1}, \beta_{2}, \ldots, \beta_{n}$. Argumentami funktorów mogą być zarówno nazwy, zdania, jak i inne funktory. Na przykład, jeżeli dany funktor tworzy zdanie z dwóch nazw, to należy oznaczyć go jako $\frac{Z}{n n}$.

\subsubsection{TEST POPRAWNOŚCI SYNTAKTYCZNEJ}

Odtworzę teraz procedurę analizy syntaktycznej wyrażenia przedstawioną przez Ajdukiewicza. Będę się trzymać ściśle jego założeń, zgodnie z którymi na podstawie składników mamy dopiero zdecydować, czym jest całość. Przyjrzyjmy się zatem warunkom spójności syntaktycznej wyrażenia.

\section{DEFINICJA 1.6. WYRAŻENIE SPÓJNE SYNTAKTYCZNIE WEDŁUG AJDUKIEWICZA}

Wyrażenie jest spójne syntaktycznie wtedy i tylko wtedy, gdy: (A) jest na wskroś dobrze ułożone, (B) człony wyrażenia tego samego rzędu odnoszące się do siebie jako funktory i argumenty odpowiadają sobie wzajemnie, (C) posiada wykładnik, który jest pojedynczym wskaźnikiem (Ajdukiewicz 1985a: 229). 
Mamy zatem warunek (A), który jest spełniony wtedy i tylko wtedy, gdy po pierwsze - ciąg wyrazów jest dobrze ułożony, czyli istnieje możliwość wskazania funktora głównego i argumentów; i gdy - po drugie - przy dalszym zstępowaniu do członów $n$-tego stopnia zawsze dochodzi się albo do wyrazów, albo do wyrażeń dobrze ułożonych. Następnie mamy warunek (B), który jest spełniony wtedy i tylko wtedy, gdy każdemu funktorowi głównemu określonego stopnia odpowiadają argumenty tego samego typu i w tej samej liczbie co we wskaźniku funktora. Na przykład, funktorowi $\frac{Z}{n n}$ muszą odpowiadać dokładnie dwa argumenty nazwowe. Jest jeszcze warunek (C), który jest spełniony wtedy i tylko wtedy, gdy na końcu analizy otrzymujemy pojedynczy wskaźnik (Ajdukiewicz 1985a: 226-229).

Mając na uwadze definicję wyrażenia spójnego syntaktycznie, możemy teraz przejść do metody analizy syntaktycznej. Sprowadza się ona do następujących kroków.

(1) Podpisz wskaźnik funktora głównego całego wyrażenia. Jeżeli nie istnieje funktor główny całego wyrażenia, nie spełnia ono warunku (A), a zatem jest niespójne syntaktycznie. Jeżeli istnieje funktor główny, przejdź do punktu (2).

Przykład: Ala przyszła do Jacka $\mathbf{i}\left[\frac{z}{z z}\right]$ Jacek był zdziwiony.

(2) Podpisz wskaźniki pozostałych składników wyrażenia. Jeżeli nie jesteś w stanie podpisać wskaźników $n$-tego stopnia w taki sposób, że możesz wyróżnić funktor i jego argumenty, wyrażenie nie spełnia warunku (A), a zatem jest niespójne syntaktycznie. Jeżeli nie napotykasz takiej przeszkody, przejdź do punktu (3).

Przykład: Ala $[n]$ przyszła do $\left[\frac{Z}{n n}\right]$ Jacka $[n]$ i $\left[\frac{Z}{z z}\right]$ Jacek $[n]$ był $\left[\frac{Z}{n n}\right]$ zdziwiony $[n]$.

(3) Uporządkuj człony wyrażenia według następującego porządku: zapisz główny funktor wyrażenia, a następnie kolejno jego pierwszy, drugi (ew. trzeci, czwarty itd.) argument. Jeżeli jakiś człon tego ciągu dalej jest wyrażeniem złożonym, porządkujemy jego człony według tej samej zasady.

Przyktad: $\quad \frac{Z}{Z Z} \frac{Z}{n n} n n \frac{Z}{n n} n n$.

(4) Idąc od lewej strony do prawej, znajdź takie „ułamki”, w których „mianownik” jest taki sam jak następujące po tych ułamkach wskaźniki. Skracaj je i zastępuj pozostałymi ,licznikami”. Po dokonaniu redukcji przepisz pozostałe wskaźniki. Jeżeli dalej masz możliwość skracania, powtarzaj procedurę, aż dotrzesz do takiego wyrażenia, którego nie da się już zredukować. Jeżeli na 
końcu redukcji otrzymasz pojedynczy wskaźnik, masz do czynienia z wyrażeniem spójnym syntaktycznie, a zatem sensownym. Jeżeli nie, to nie spełnia warunku (B), a zatem jest niespójne syntaktycznie. Przykład:

a) $\frac{Z}{Z Z} \frac{Z}{n n} n n \frac{Z}{n n} n n$

b) $\frac{Z}{Z Z} \frac{Z}{n n} \cap n \frac{Z}{n n} \cap A$

c) $\frac{z}{z z} z z$

d) $z$ (pojedynczy wskaźnik, czyli jest to sensowne wyrażenie języka polskiego)

Kiedy przeprowadzimy cały test i wszystkie warunki będą spełnione, to na gruncie teorii Ajdukiewicza można powiedzieć, że wyrażenie jest spójne syntaktycznie, czyli jest sensownym wyrażeniem języka polskiego.

\section{AJDUKIEWICZ O WYRAŻENIACH NIEPEŁNYCH}

Po omówieniu metody Ajdukiewicza przejdźmy do problemu jej zastosowania do wyrażeń eliptycznych i niedopowiedzeń. Zacznijmy od zbadania, co sam Ajdukiewicz o nich mówil. $W$ jego pracach przewijają się zasadniczo dwa pojęcia związane $\mathrm{z}$ brakiem $\mathrm{w}$ wyrażeniach: niedopowiedzenia i wyrażenia eliptyczne. Musimy najpierw sprawdzić, czy to rozróżnienie ma dla niego jakieś ważne znaczenie, czy jest tylko efektem odmiennej konwencji pojęciowej w różnych pracach.

\subsection{NIEDOPOWIEDZENIA}

W Logice pragmatycznej Ajdukiewicz (1965: 54-61) opisuje defekty semiotyczne, które dzieli na wady języka, wady znaczenia i wady sposobu mówienia. Nas interesują te trzecie, wśród których Ajdukiewicz wyróżnia coś, co nazywa niedopowiedzeniami. Wskazuje na ich dwa rodzaje: niedopowiedzenia kwantyfikacji i niedopowiedzenia relatywizacji.

Z niedopowiedzeniami kwantyfikacji, pisze Ajdukiewicz, mamy do czynienia wtedy, gdy w wypowiedzi brakuje kwantyfikatora, mimo że zdecydowanie powinien się tam pojawić, ponieważ bez niego nie można wskazać znaczenia wyrażenia (Ajdukiewicz 1965: 61). Przykładem może być wyrażenie „Anglicy są flegmatyczni”. Brak kwantyfikatora prowadzi do sytuacji, w której nie wiemy, o ilu Anglików chodzi. Przyjmijmy, że $P(x)$ oznacza „ $x$ jest Anglikiem”, 
a $R(x)$ oznacza, że „x jest flegmatyczny”. Spójrzmy na możliwe uzupełnienia kwantyfikatorem:

1. „Wszyscy Anglicy są flegmatyczni”: $\forall x(P(x) \rightarrow R(x))$.

2. „część (większość/mniejszość/połowa) Anglików jest flegmatyczna": $\exists x(P(x) \wedge R(x))$.

3. „Tylko Anglicy są flegmatyczni”: $\forall x(R(x) \rightarrow P(x))$.

Drugim rodzajem niedopowiedzenia jest niedopowiedzenie relatywizacji. Powstaje ono wtedy, gdy przyczyną niedopowiedzenia jest brak istotnego funktora, który nie jest kwantyfikatorem. Ajdukiewicz (1961: 61) podaje jako przykład wyrażenie „kąpiel w rzece służy zdrowiu”. Zaznacza, że błąd polega na niedookreśleniu, o czyje zdrowie chodzi. Gdyby na przykład w jakiejś sytuacji opuszczonym składnikiem było „mojemu”, to wyrażenie pełne wyglądałoby tak: „kąpiel w rzece służy mojemu zdrowiu”. Domyślenie się składnika nie zawsze jest proste - w pewnych kontekstach może to być bardzo trudne.

Zdaniem Ajdukiewicza (1965: 61) wyrażenia, które są niedopowiedzeniami relatywizacji, są pozbawione sensu. Pisze, że znaczenia niedopowiedzeń domyślać się można na różne sposoby, co prowadzi do nieporozumienia. Podobnie wygląda dla niego sprawa niedopowiedzeń kwantyfikacji.

Bez tego składnika wypowiedź ta nie jest prawdą ani fałszem [jest pozbawiona sensu], a więc nie jest zdaniem; może ona stać się prawdą, ale może też być fałszem, zależnie od tego, jak ją uzupełnimy (Ajdukiewicz 1965: 61).

Dalej jednak zauważa, że czasami można się domyślić składnika. Powstają więc dwa problemy interpretacyjne. Pierwszy: czy niedopowiedzenia relatywizacji i niedopowiedzenia kwantyfikacji wyczerpują zdaniem Ajdukiewicza cały zbiór niedopowiedzeń? I kolejny problem: czy każdy brak kwantyfikatora w wypowiedzi jest niedopowiedzeniem (to znaczy nawet wtedy, gdy odbiorca od razu domyśla się z kontekstu, o kogo chodzi), czy tylko wtedy, gdy nie jest domyślny?

Trudno jednoznacznie to stwierdzić, chociaż wydaje się, że sam brak kwantyfikatora w wypowiedzi jest już zdaniem Ajdukiewicza błędem niedopowiedzenia - sugerowałby to sposób, w który opisuje to zagadnienie. W tym sensie „błąd niedopowiedzenia” ma to samo znaczenie co „niedopowiedzenie” i każdorazowy brak kwantyfikatora jest niedopowiedzeniem. To natomiast nie pokrywałoby się z moją definicją niedopowiedzenia, ponieważ zgodnie z nią to nie sama struktura wypowiedzianego zdania pozwala na rozpoznanie niedopowiedzenia, lecz to, czy ten brak powoduje niezrozumiałość wypowiedzi $\mathrm{w}$ danej sytuacji. Celowo nie podałem jakiegoś syntaktycznego wzoru niedopowiedzenia, ponieważ w pewnych kontekstach brak kwantyfikatora może nie 
być przeszkodą w zrozumieniu wypowiedzi i wtedy będziemy mieli do czynienia z wyrażeniem eliptycznym, a nie niedopowiedzeniem (zgodnie z przyjętą tu terminologią).

\subsection{NIEDOPOWIEDZENIA A WYRAŻENIA ELIPTYCZNE}

Gdy próbujemy zrozumieć stanowisko Ajdukiewicza w sprawie wyrażeń eliptycznych i niedopowiedzeń, pojawiają się pewne problemy terminologiczne. Czy Ajdukiewicz również odróżnia wyrażenia eliptyczne od niedopowiedzeń? Czy uważa je za to samo? Ustalmy wpierw, co wiemy na pewno. W Logice pragmatycznej pisze, że „błąd niedopowiedzenia popełniamy, gdy w jakimś wyrażeniu opuszczamy jakiś istotny jego składnik" (Ajdukiewicz 1965: 61). W podobnym sensie w pracy Pewna metoda eliminacji intensjonalnych zdan i formul zdaniowych mówi o czymś, co uznaje za wyrażenia eliptyczne (Ajdukiewicz 1985b: 367). Podaje tam przykład wyrażenia „Cezar wiedział, że stolica papiestwa leży nad Tybrem” i pisze o nim, że może ono być uzupełnione na dwa sposoby: „Cezar wiedział o stolicy papiestwa, o Tybrze i o relacji leżenia, że stolica papiestwa leży nad Tybrem” oraz „Cezar wiedział o stolicy, o papiestwie, o Tybrze i o relacji leżenia, że stolica papiestwa leży nad Tybrem". Dalej, ze względu na możliwie różne uzupełnienia, wnioskuje, że są to wyrażenia eliptyczne i że ta eliptyczność jest przyczyną wieloznaczności. Zauważa, że drogą do eliminacji wieloznaczności eliptycznej jest albo wstrzymanie się od jej stosowania, albo ustalenie sensu sformułowań eliptycznych. Mimo że mówi tutaj o wyrażeniu eliptycznym, moglibyśmy przecież bez problemu uznać to wyrażenie za jakiś rodzaj niedopowiedzenia. Porównując zatem jego uwagi dotyczące niedopowiedzeń z Logiki pragmatycznej i przytoczone spostrzeżenia o wyrażeniach eliptycznych, możemy przypuszczać, że niedopowiedzenia i wyrażenia eliptyczne są dla Ajdukiewicza tym samym. Zarówno w przypadku niedopowiedzeń, jak i podanych tutaj wyrażeń eliptycznych Ajdukiewicz bardzo mocno zaznacza, że w gruncie rzeczy chodzi o to, że brak składnika prowadzi do wieloznaczności.

Wątpliwości co do takiej interpretacji budzi inna jego praca. W O spójności syntaktycznej Ajdukiewicz (1985a: 226-227) pisze, że w języku występują wyrażenia eliptyczne, wobec czego sensowne wyrażenia złożone mogą nie być na wskroś dobrze ułożone. Jako rozwiązanie wskazuje dołączenie domyślnych słów opuszczonych. I tutaj powstaje pewien problem: tym razem Ajdukiewicz kładzie nacisk na to, że wyrażenia eliptyczne są sensowne, a więc można dołączyć domyślne słowa opuszczone. Wydaje się zatem, że wyrażenie eliptyczne jest dla niego czymś innym, ewentualnie traktuje to pojęcie szerzej niż pojęcie 
niedopowiedzenia, to znaczy niedopowiedzenia są jakimś rodzajem wyrażeń eliptycznych ${ }^{8}$.

Nie wiadomo zatem, jak ostatecznie Ajdukiewicz rozumiał stosunek między niedopowiedzeniami a wyrażeniami eliptycznymi. Można jednak przypuszczać, że tak samo jak przyjąłem w tej pracy, dzielił braki składniowe na takie, które prowadzą do wieloznaczności, i takie, które tego nie robią (skoro można się ich domyślić), a zatem na takie, które powodują bezsensowność, i takie, które jej nie powodują. Musimy mieć jednak na uwadze, że między terminologią przyjętą $\mathrm{w}$ tej pracy a terminologią, którą posługuje się Ajdukiewicz, istnieją różnice.

\subsubsection{WADLIWOŚĆ NIEDOPOWIEDZEŃ}

Po uwagach terminologicznych raz jeszcze wróćmy do wątku niedopowiedzeń. Jak już wspominałem na początku tej części, Ajdukiewicz (1965: 61) w Logice pragmatycznej nazywa niedopowiedzenia wadami sposobu mówienia. Nakierowuje zatem naszą uwagę na używanie języka. Warto tutaj wspomnieć o pracy Chybińskiej (2015: 207) na temat defektów semiotycznych u Ajdukiewicza, w której autorka trafnie zauważa, że wady te są u Ajdukiewicza wykroczeniami przeciwko semiotyczno-logicznej poprawności wyrażeń. Winą za te wykroczenia Ajdukiewicz obarcza, jak się zdaje, użytkowników języka. Odróżnia niedopowiedzenia od innych wad, takich jak wieloznaczności, będące wadą języka, i nieostrości, będące wadą znaczenia, wskazując na to, że niedopowiedzenia są wadami użycia, czyli aktywnego stosowania języka. Jak zauważa Chybińska (2015: 207), Ajdukiewiczowi chodzi o to, że mimo iż użytkownik mógł sformułować kompletną wypowiedź, to z jakiegoś powodu zdecydował się tego nie zrobić. Przyczyna tej wady nie tkwi zatem w samym wyrażeniu, tak jak w przypadku pozostałych wad, lecz leży po stronie człowieka.

Weźmy na przykład błąd wieloznaczności. Zgodnie z tym, co pisze o nim Ajdukiewicz (1965: 54-55), jest on ściśle związany z przyjętą konwencją terminologiczną i zwyczajem, które przyporządkowują wyrażeniu więcej niż jedno znaczenie. Tak jest na przykład w przypadku wyrazu „zamek”. Wina tutaj jednak nie leży po stronie użytkownika języka, lecz konwencji. Użytkownik używa tego wyrażenia zgodnie z jego przeznaczeniem. Podobnie jest w przypadku wyróżnionej przez niego nieostrości (Ajdukiewicz 1965: 58-59). Fakt, że w przypadku pewnych nazw nie jesteśmy w stanie określić, czy wskazywane przez nie desygnaty są ich wszystkimi desygnatami, to niedoskonałość związana z samą nazwą, a nie jej używaniem. W przypadku niedopowiedzenia

\footnotetext{
${ }^{8} \mathrm{~W}$ tym sensie wyrażenia eliptyczne obejmowałyby u niego takie wyrażenia, w których brak powoduje bezsensowność, i takie, w których wypadku można się domyślić, jak uzupełnić brak. Byłoby to zatem to samo, co wyrażenia niepełne w tym artykule.
} 
wieloznaczność nie tkwi w samym semantycznym znaczeniu wyrażenia, lecz w jego użyciu.

Płyną z tego dwa interesujące wnioski. Po pierwsze, zważywszy na to, że takie niedopowiedzenia skutkują wieloznacznością, Ajdukiewicz uważa je za źródło codziennych nieporozumień. Po drugie, Ajdukiewicz niespecjalnie zajmuje się problemem, z którym mierzy się zewnętrzny badacz takich wypowiedzi, lecz raczej interesuje go sytuacja bezpośredniego odbiorcy, do którego wypowiedź była skierowana. To z kolei jest zgoła inna perspektywa niż ta, która mnie tutaj interesuje. Będę bowiem zastanawiać się nad sytuacją badacza zewnętrznego, który dostaje taką wypowiedź na kartce papieru i ma zadecydować o jej sensowności za pomocą metody analizy syntaktycznej.

\section{ANALIZA SYNTAKTYCZNA WYRAŻEŃ JĘZYKA NATURALNEGO}

W tej części pokażę, w jaki sposób można wykorzystać istnienie wyrażeń niepełnych, aby podważyć zastosowanie analizy syntaktycznej jako narzędzia do sprawdzania sensowności wyrażeń języka naturalnego. Tezę pracy wykażę w dwóch krokach. Wpierw, na przykładzie różnych wypowiedzi, przedstawię problemy, które powstają przy stosowaniu analizy syntaktycznej do wyrażeń niepełnych. W drugim kroku wykorzystam te problemy, aby uzasadnić główny zarzut przeciwko stosowaniu tej metody do języków naturalnych.

\subsection{PROBLEMY ANALIZY NIEDOPOWIEDZEŃ}

Przypomnijmy wpierw, że Ajdukiewicz zakłada explicite, że wyrażenie jest spójne syntaktycznie wtedy i tylko wtedy, gdy jest sensowne (ma jednolite znaczenie). Widzimy tutaj działającą w dwie strony implikację, to znaczy (1) jeżeli wyrażenie jest spójne syntaktycznie, to jest sensowne i (2) jeżeli wyrażenie jest sensowne, to jest spójne syntaktycznie. Ajdukiewicza interesuje przede wszystkim implikacja (1) ze względu na to, że jego metoda właśnie na niej bazuje. Przekonanie o jej prawdziwości stanowi trzon całej procedury, która ma sprawdzać, czy mamy do czynienia z sensem, czy bezsensem. Wydaje się to bardzo wygodne - wystarczy, że wykażemy spójność syntaktyczną wyrażenia i już wtedy powinniśmy mieć pewność, że ma ono określone znaczenie. Weźmy zatem zdanie „Anglicy są flegmatyczni”. Sprawdźmy, czy to wyrażenie jest spójne syntaktycznie.

a) Anglicy $[n]$ są $\left[\frac{Z}{n n}\right]$ flegmatyczni $[n]$ 
b) $\frac{Z}{n n} A n$

c) $z$

W rezultacie uzyskaliśmy wynik wskazujący, że wyrażenie jest spójne syntaktycznie, a zatem, zgodnie z założeniem Ajdukiewicza, ma jednolite znaczenie. Mamy tutaj spełnione oba warunki spójności. Po pierwsze, wyrażenie jest na wskroś dobrze ułożone, to znaczy możemy wskazać główny funktor „są” i jego argumenty „Anglicy” i „flegmatyczni”. Po drugie, argumenty „Anglicy” i „flegmatyczni” odpowiadają funktorowi „są" - zarówno liczebnie, jak i pod względem przynależności do kategorii syntaktycznych. Zauważmy jednak, że brak kwantyfikatora często prowadzi do powstania niedopowiedzenia, które jest wyrażeniem bezsensownym. Możemy też dopuścić przypadki, w których takie wyrażenie da się zrozumieć i wtedy jest to zwykłe wyrażenie eliptyczne. To, czy takie wyrażenie możemy jednak uznać za niedopowiedzenie, czy też nie, zależy od warunków jego użycia. Docieramy zatem do pewnego problemu: analiza syntaktyczna zawsze wykaże, że to wyrażenie jest sensowne, mimo że wszystko zależy od warunków jego użycia - w pewnych kontekstach może mieć ono sens, w innych nie.

Weźmy jeszcze jeden przykład wyrażenia, które bardzo często jest niedopowiedzeniem relatywizacji: „Kąpiel w rzece służy zdrowiu”.

$$
\begin{aligned}
& \text { a) Kąpiel }[n] \text { w }\left[\frac{n}{n n}\right] \text { rzece }[n] \text { służy }\left[\frac{Z}{n n}\right] \text { zdrowiu }[n] \\
& \text { b) } \frac{Z}{n n} \frac{n}{n n} A \text { An } \\
& \text { c) } \frac{Z}{n n} A n \\
& \text { d) } z
\end{aligned}
$$

Znaleźliśmy funktor główny całego wyrażenia, którym jest „służy”, a także jego argumenty „kąpiel w rzece” i „zdrowiu”. Dalej, rozkładając wyrażenie „kąpiel w rzece”, otrzymaliśmy jego funktor główny „w” i argumenty „kąpiel” i „rzece”. Warunek na wskroś dobrego ułożenia jest zatem spełniony. Warunek drugi, który dotyczy odpowiedniości funktorów i jego argumentów, również jest tutaj zrealizowany: dla funktora "służy” mamy odpowiednio do jego mianownika dwa argumenty nazwowe „kąpiel w rzece” i ,zdrowiu”, a dla funktora „w” odpowiednio dwa argumenty nazwowe „kąpiel” i „rzece”. Procedura zatem przeprowadzona jest poprawnie - oto mamy wyrażenie spójne syntaktycznie, a więc sensowne. A jednak, jak wiemy z wcześniejszych rozważań, często będzie ono bezsensowne, ponieważ brakuje w nim określenia, o czyje zdrowie chodzi. Zastanówmy się zatem, co moglibyśmy zrobić, aby poradzić sobie z tymi pro- 
blemami, tzn. uniknąć sytuacji, w której mamy do czynienia z niedopowiedzeniem, a analiza pokazuje nam błędnie, że to wyrażenie jest sensowne.

(1) Moglibyśmy oczywiście spróbować uznać, że wszystkie niedopowiedzenia są bezsensowne, niezależnie od tego, czy są spójne syntaktycznie, czy też nie. Wtedy musielibyśmy zmodyfikować założenie Ajdukiewicza, że wyrażenie jest spójne syntaktycznie wtedy i tylko wtedy, gdy jest sensowne, w następujący sposób: dla dowolnego wyrażenia, które nie jest niedopowiedzeniem, jest tak, że wyrażenie jest spójne syntaktycznie wtedy i tylko wtedy, gdy jest sensowne. $\mathrm{W}$ ten sposób zwalniamy niedopowiedzenia $\mathrm{z}$ wymogu bycia sensownymi, gdy są poprawnie zbudowane i z wymogu bycia poprawnie zbudowanymi, gdy są sensowne, a zatem likwidujemy konieczność sprawdzania ich spójności. Następnie musielibyśmy dodać nowe założenie, że dla dowolnego niedopowiedzenia jest tak, że jest ono bezsensowne. To z kolei wymagałoby od nas dodania jakiegoś testu wstępnego, który sprawdzałby, czy rzeczywiście mamy do czynienia z niedopowiedzeniem. Wtedy po jego przeprowadzeniu uznawalibyśmy automatycznie niedopowiedzenia za bezsensowne i nie poddawalibyśmy ich analizie syntaktycznej Ajdukiewicza.

(2) Drugą możliwością jest uznanie, że wszystkie niedopowiedzenia są niepoprawnie zbudowane. Wtedy nie ma potrzeby modyfikacji podstawowego założenia Ajdukiewicza, że wyrażenie jest spójne syntaktycznie wtedy i tylko wtedy, gdy jest sensowne, a zatem przynajmniej wnioskowanie byłoby poprawne. Musielibyśmy jednak dodać do samej procedury analizy syntaktycznej regułę, zgodnie z którą jeżeli wyrażenie jest niedopowiedzeniem, to z góry pomijamy redukcję i uznajemy je za niespójne syntaktycznie bez przeprowadzenia analizy. To jednak, tak samo jak pierwsze rozwiązanie, wymaga dodania jakiegoś dodatkowego testu, który wykrywałby, że mamy do czynienia z niedopowiedzeniem.

Oba te rozwiązania są problematyczne. Pierwsze rozwiązanie modyfikuje podstawowe założenie całej metody, przyznając, że nie da się przez analizę spójności sprawdzić, czy są one bezsensowne, czy też nie. Musimy zatem w jakiś sposób wyłączyć takie wyrażenia $\mathrm{z}$ analizy syntaktycznej. W podanym rozwiązaniu robimy to, modyfikując podstawowe założenia analizy syntaktycznej. To jednak nieuchronnie prowadzi do innego problemu. Skoro wyłączamy niedopowiedzenia, to musimy wpierw ustalić, że mamy z nimi do czynienia. Żeby to zrobić, trzeba najpierw zdecydować, czy mamy do czynienia $\mathrm{z}$ wyrażeniem sensownym, czy też bezsensownym. Musimy zatem ustalić coś, co analiza syntaktyczna ma dopiero wykazać. 
Z kolei drugie rozwiązanie prowadzi do bardzo dziwacznych wniosków. $\mathrm{Z}$ jakiegoś powodu uznajemy, że wszystkie wyrażenia z niedopowiedzeniem są niepoprawnie zbudowane, mimo że przy zastosowaniu do nich definicji spójności syntaktycznej ewidentnie widzimy, że spełniają one jej warunki. Robimy tak tylko dlatego, że metoda w ich przypadku nie działa i zmuszeni jesteśmy uznać je za niespójne bez jakiejkolwiek analizy. To jednak również prowadzi do podobnego problemu. Tak samo jak w przypadku rozwiązania pierwszego, musimy wpierw rozpoznać, że w ogóle mamy do czynienia z niedopowiedzeniem, a więc ustalić bezsensowność wyrażenia.

To pokazuje, że nie możemy na ślepo korzystać z analizy syntaktycznej. Jeżeli wcześniej nie rozpoznamy, że wyrażenie jest bezsensowne, to znaczy ograniczymy się do samej analizy syntaktycznej, dojdziemy do błędnych rozstrzygnięć, ponieważ analiza syntaktyczna uparcie będzie pokazywać, że wyrażenie jest spójne syntaktycznie. Żeby zauważyć ten problem, musimy wyjść poza samą metodę i spojrzeć na nią z zewnątrz, to znaczy zauważyć najpierw, że wyrażenie jest bezsensowne, a przyczyną tej bezsensowności jest niedopowiedzenie, i wskazać, że analiza syntaktyczna prowadzi do błędnego rozstrzygnięcia, czyli stwierdza, że wyrażenie jest sensowne, mimo że takie nie jest. Musimy zatem za każdym razem, gdy analizujemy wyrażenie, zadać sobie następujące pytanie: czy to wyrażenie jest niedopowiedzeniem? Parafrazując, pytamy najpierw, czy wyrażenie jest sensowne, czy też nie. A przecież odpowiadając na to pytanie, stwierdzamy coś, co dopiero ma być wykazane.

\subsection{PROBLEM WYRAŻEŃ ELIPTYCZNYCH}

Do podobnych problemów dojdziemy, wychodząc od wyrażeń eliptycznych zamiast niedopowiedzeń. Przypomnijmy, że Ajdukiewicz pisze, iż zdarza się, że sensowne wyrażenia mogą być eliptyczne, w wyniku czego nie są na wskroś dobrze ułożone, gdy bierze się pod uwagę wyłącznie wyrazy w nich zawarte. Można jego zdaniem osiągnąć takie wyrażenie, gdy dołączy się domyślne słowa opuszczone (Ajdukiewicz 1985a: 226-227). Określenie „domyślne słowa opuszczone” nastręcza jednak wielu trudności. Najłatwiej uzupełnić, jak się zdaje, wyrażenia eliptyczne, które mają charakter formalnosyntaktyczny. Wtedy wypełnienie takiego braku jest czysta formalnościa, ponieważ wystarczy znać schemat formalnosyntaktyczny wyrażenia. Spójrzmy na następujące przykłady:

1. Bardzo się mylisz.

2. Byłem chory. 
Kiedy weźmiemy którekolwiek z tych wyrażeń i spróbujemy dokonać jego analizy syntaktycznej, dojdziemy do wniosku, że te wyrażenia są niespójne syntaktycznie, mimo że intuicyjnie wiemy, że mają sens. Jednakże w przypadku tych wyrażeń możemy z łatwością uzupełnić braki, ponieważ nie wymagają one w ogóle kontekstu. Wystarczy, że znamy ich schemat formalnosyntaktyczny. Widzimy, że w przypadku wyrażenia (1) wyelidowanym składnikiem jest podmiot „ty”. Wskazuje nam to schemat formalnosyntaktyczny wyrażenia „mylisz się”, to znaczy z nim zawsze łączy się, zgodnie z polskim regułami językowymi, zaimek osobowy „ty”. Po uzupełnieniu możemy dokonać analizy syntaktycznej:

$$
\begin{aligned}
& \text { a) Ty }[n] \text { bardzo }\left[\frac{\frac{z}{n}}{\frac{z}{n}}\right] \text { się mylisz }\left[\frac{z}{n}\right] \\
& \text { b) } \frac{\frac{z}{n}}{\frac{z}{z}} \frac{z}{\hbar} n \\
& \text { c) } \frac{z}{n} n \\
& \text { d) } z
\end{aligned}
$$

Z kolei w przypadku wyrażenia (2) wyelidowanym składnikiem okazuje się podmiot ,ja”. Znów nie potrzebujemy tutaj kontekstu, wystarczy nam sama znajomość schematu formalnosyntaktycznego wyrażenia, żeby wiedzieć, że brakuje tam podmiotu. Predykat „byłem” wymusza na nas uzupełnienie tego wyrażenia zaimkiem ,ja”. Wtedy możemy znowu z latwością przeprowadzić analizę syntaktyczną:
a) Ja $[n]$ byłem $\left[\frac{Z}{n n}\right]$ chory $[n]$
b) $\frac{Z}{m n} n A$
c) $z$

Jak się zdaje, możemy zmodyfikować metodę analizy syntaktycznej w taki sposób, żeby uzupełniać takie elementy wyelidowane. W sytuacji, gdy musimy się odwołać do samego schematu wyrażenia, jesteśmy w stanie zapewne skonstruować algorytm decydujący o tym, jakie wyrażenie należy wstawić w brakującym miejscu. Taki algorytm wypełniania wyrażeń eliptycznych izolowanych doprowadziłby nas jednak do pewnego problemu. Spójrzmy na wyrażenie „Jestem przeziębiony”. Z łatwością wypełniamy brakujący zaimek osobowy, to znaczy „[Ja] jestem przeziębiony”. Dlaczego nie dodajemy nic więcej? Dlaczego nie wpiszemy na przykład „[Ja] jestem [zimno] przeziębiony”? Jest tak dlatego, że uznajemy, iż dwa wyrażenia, tzn. „Jestem przeziębiony” i „Ja 
jestem zimno przeziębiony" nie są ze sobą tożsame treściowo, czyli że wyrażają coś innego. Ustalamy zatem, że osiągnęliśmy granicę wypełnienia i nic więcej dodać nie możemy, ponieważ wtedy zmienimy wypowiedź na inną, w najgorszym wypadku na taką, która jest bezsensowna.

W tym algorytmie potrzebne byłoby kryterium, na mocy którego uznaje się, że osiągnęliśmy granicę wypełnienia. Żeby to zrobić, należy wpierw określić, jaki ma ono sens, a zatem wcześniej rozpoznać, że jest ono w ogóle sensowne. Znowu zatem musimy założyć coś, co dopiero ma zostać wykazane. Do tego samego problemu dotrzemy, wychodząc od wyrażeń eliptycznych innego rodzaju, to znaczy takich, które wypełnia się, odwołując do czegoś innego niż schemat formalnosyntaktyczny - do kontekstu.

Konieczna jest tu krótka dygresja. Zastanówmy się, co mamy na myśli, mówiąc „metoda”. Najogólniej rzecz biorąc, wiemy, że metoda jest pewnego rodzaju przepisem - klarownie i precyzyjnie opisanym sposobem postępowania, aby osiągnąć jakiś cel. Natomiast metoda naukowa jakiejś dyscypliny, czyli metoda stosowana $\mathrm{w}$ tej dyscyplinie, to metoda uzgodniona, wspólna i zaakceptowana $\mathrm{w}$ danej dziedzinie jako sposób docierania do rezultatów. Jest to zatem taki przepis, który ma zapewnić intersubiektywną sprawdzalność wyników. Wiedza naukowa, żeby właśnie była naukowa, musi poddawać się kontroli. Konieczne staje się zatem podanie określonej i wykonalnej przez każdego wykwalifikowanego naukowca procedury dochodzenia do wyników. I chociaż metody logiki i matematyki nie mają związku z empirią, reguła pozostaje ta sama: musi być spełniony warunek intersubiektywności. Stąd też nie ulega wątpliwości, że sama analiza syntaktyczna jest metodą. Jej wyniki są intersubiektywnie komunikowalne, dlatego że dowolny podmiot, który dysponuje odpowiednią wiedzą z zakresu logiki, jest w stanie ją zastosować i dotrzeć do tego samego wyniku.

Może być tak, że w ramach metody dochodzimy do błędnych wniosków. Nie zmienia to jednak faktu, że dowolna osoba zapoznana z teorią, gdy zastosuje tę procedurę, dotrze do tego samego rezultatu. Nawet jeżeli w przypadku niedopowiedzeń analiza daje błędny wynik, to musimy przyznać, że inny wykwalifikowany logik, gdy ją zastosuje, dotrze do tego samego rezultatu. W tym sensie nadal jest to metoda, ponieważ istnieje skończona liczba kroków, która pozwala dotrzeć do celu.

Żeby lepiej to zobrazować, wróćmy na chwilę do niedopowiedzeń Ajdukiewicza. Weźmy wyrażenie „Polacy kupują samochody”. Spójrzmy na algorytm podany przez Ajdukiewicza (por. wyżej, 1.2.2). Przeprowadźmy analizę tego wyrażenia.

a) Polacy $[n]$ kupują $\left[\frac{Z}{n n}\right]$ samochody $[n]$. 


\author{
b) $\frac{Z}{n n} A \cap$ \\ c) $z$
}

Ustaliliśmy wcześniej, że takie wyrażenia mogą być bezsensowne, mimo że przeprowadzona analiza pokazuje, iż wyrażenie jest spójne syntaktycznie. Zauważmy jednak, że nie odbiera to tej procedurze miana metody. Niezależnie od tego, który semiotyk przeprowadzi tę analizę, każdy dojdzie do tego samego błędnego rezultatu, że jest to wyrażenie sensowne. Jak zatem widać, analiza jest intersubiektywnie sprawdzalna i komunikowalna. Dlatego też trzeba zaznaczyć, aby uniknąć ewentualnych nieporozumień, że nie podważam tego, że mamy do czynienia z metodą. Podaję jedynie w wątpliwość jej samowystarczalność.

Spróbujemy teraz odpowiedzieć na pytanie, czy jesteśmy w stanie metodycznie zdecydować o wypełnieniu wyrażeń eliptycznych na podstawie kontekstu. Rozważę argumenty za i przeciw, a następnie pokażę, że każdy z tych argumentów prowadzi ostatecznie do tego samego problemu, z którym borykaliśmy się wcześniej.

Zacznijmy od pytania: czy możemy, jako zewnętrzni badacze, dotrzeć do kontekstu? I, co ważniejsze, czy możemy zrobić to według określonego algorytmu? Stanowisko przeciw mówiłoby, że kontekst nie jest czymś, co daje się zamknąć w ścisłe ramy. Wtedy musimy przyznać, że odkrywamy go drogą intuicyjną, a nie za pomocą określonej i sprecyzowanej metody. Możliwy jest zatem spór co do tego, w jakim kontekście językowym albo sytuacyjnym osadzone jest wyrażenie i, co za tym idzie, jakie wyrażenie zostało wyelidowane.

$\mathrm{Na}$ poparcie takiego stanowiska możemy przedstawić pewien przykład. Załóżmy, że wchodzimy do pokoju i słyszymy, że osoba B mówi do osoby A: „To Jacek”. Chcemy zbadać poprawność syntaktyczną tej wypowiedzi. Widzimy, że nastąpiło tu opuszczenie składnika, a my chcemy odkryć jakiego. Przeprowadzamy pewne obserwacje: osobą B jest pięcioletni chłopiec, osobą A jest jego matka. Wiemy, że osoba B ma brata o imieniu Jacek. Możemy wyprowadzić pewne przypuszczenie: osoba B zrzuca winę na Jacka. Możliwe zatem, że próbuje powiedzieć następujące zdanie „To Jacek [rozrzucił zabawki]”. Zauważmy jednak, że mogło być zupełnie inaczej. Mogło być na przykład tak, że osoba A zadała następujące pytanie: „Jak nazywa się twoja zabawka?”, a osoba B odpowiedziała: ,,To [jest] Jacek”. Bylibyśmy zatem w błędzie. Okazałoby się, że nie znaliśmy całego kontekstu. Ten przykład pokazuje, że dwóch różnych badaczy może dojść do zupełnie innych wniosków co do tego, jakie powinno być wypełnienie. Badają wtedy dwa zdania o zupełnie innej treści.

Czy da się podać jakiś algorytm nieodwołujący się do sensu? Widzimy, że brakuje tutaj orzeczenia. Nie istnieją żadne czysto syntaktyczne wskazówki, 
jakie to ma być orzeczenie. Musimy odwołać się do kontekstu. Jeżeli obierzemy stanowisko przeciw, to powiemy, że nie da się kontekstu zamknąć w ścisłe ramy. Zazwyczaj bowiem w przypadku jego badania nie wiemy, czy znamy dostatecznie duży jego fragment. Nie mamy nawet pewności, kiedy osiągamy już dostateczną wiedzę. Musimy zatem przyznać, że jest to procedura bardziej intuicyjna niż ścisła. Za każdym razem, gdy w grę wchodzi kontekst, metoda nie może zaistnieć, ponieważ kontekst jest zjawiskiem na tyle złożonym i subiektywnym, że nie może zostać zobiektywizowane, nabrać mocy intersubiektywnej. Nawet w przypadku, gdy mamy do czynienia z bezpośrednim doświadczeniem kontekstu (jego badacze uczestniczą w sytuacji komunikacyjnej), to dwie osoby mogą zupełnie różnie zrozumieć komunikat. Jest tak dlatego, że nie ma żadnego algorytmu rozumienia komunikatów kontekstowych. Bazujemy na naszej dotychczasowej wiedzy, intuicji, głównie domniemaniu, co nadawca ma na myśli.

Przy podtrzymaniu takiego stanowiska dotyczącego kontekstu, przyznajemy, że nie można zbudować żadnej metody wypełniania takich wyrażeń eliptycznych, a zatem w szczególności metody, która wychodziłaby od syntaktyki, a nie od ustalania sensu. Musimy wpierw intuicyjnie ustalić, czy wyrażenie jest sensowne, czy też nie, a następnie, zgodnie z naszymi intuicjami, wypełnić wyrażenie eliptyczne i dokonać analizy syntaktycznej. To jednak prowadzi do błędnego koła, ponieważ musimy wpierw ustalić, co prawda tylko intuicyjnie, czy wyrażenie jest sensowne i jaki ono ma sens.

Jeśli zaś ktoś uważałby, że można by podać jakąś listę warunków pozwalających zadecydować, że kontekst jest całkowicie określony (a więc broniłby stanowiska $z a$ ), w żaden sposób nie rozwiązuje to konieczności ustalania sensu przed analizą syntaktyczną. Jak wiemy, metoda wypełniania wyrażeń eliptycznych, żeby mogła uzupełniać metodę analizy syntaktycznej, musi wychodzić od syntaktyki. Czy taka hipotetyczna metoda sprawdzania kontekstu może wychodzić od syntaktyki? Z pewnością nie. Szukanie warunków, które muszą zostać spełnione, aby poznać kontekst, to de facto poszukiwanie odpowiedzi na pytanie, jaki sens (znaczenie) ma podane wyrażenie. A zatem wpierw trzeba ustalić, że w ogóle wyrażenie jest sensowne. To z kolei ponownie prowadzi do błędnego koła - ustalamy sens zanim przystąpimy do sprawdzania sensu.

\subsection{WNIOSKI Z ANALIZOWANYCH PRZYKŁADÓW}

Teraz zastanówmy się nad tezą, zgodnie z którą istnienie wyrażeń eliptycznych w językach naturalnych sprawia, że nie można rozstrzygać o sensowności żadnych wyrażeń języków naturalnych za pomocą metody analizy syntaktycznej Ajdukiewicza. 
Zauważmy, do jakich wniosków prowadzą dotychczasowe rozważania: żeby $\mathrm{w}$ ogóle rozpoznać wyrażenia niepełne, musimy najpierw spojrzeć na nie z poziomu semantycznego, to znaczy ocenić, że takie wyrażenia są sensowne lub bezsensowne. Samo określenie „wyrażenie eliptyczne” albo „niedopowiedzenie" zakłada już decyzję, czy wyrażenie jest sensowne, czy też nie.

I tutaj docieramy do końcowego argumentu, który uzasadnia postawioną w pracy tezę. Za każdym razem gdy mówimy o jakimś wyrażeniu niepełnym, określamy to dzięki odniesieniu się do sensowności albo bezsensowności wyrażenia. Najpierw decydujemy, czy wyrażenie jest sensowne, czy też nie, a potem, czy jest ono niepełne, czy też nie, żeby wreszcie zdecydować, czy ta niepełność to wyrażenie eliptyczne, czy też może niedopowiedzenie. Nigdy odwrotnie.

Wyrażenie eliptyczne, jak wcześniej zdefiniowaliśmy, jest wyrażeniem, które mimo braku składniowego jest sensowne (zrozumiałe). Niedopowiedzenie zaś sprawia, że wyrażenie nie może być zrozumiane, ponieważ brakuje w nim istotnego składnika. Stwierdzenie, że wyrażenie jest wyrażeniem eliptycznym albo niedopowiedzeniem to dwie $\mathrm{z}$ wielu możliwych odpowiedzi na pytanie, dlaczego rozumiemy dane wyrażenie (dlaczego ma ono sens) albo dlaczego go nie rozumiemy (nie ma sensu).

Prześledźmy to na dwóch przykładach. Gdy weźmiemy wyrażenie „byłem wczoraj w sklepie”, to najpierw określamy, że rozumiemy takie wyrażenie, czyli że ma ono dla nas sens, następnie decydujemy, że jest to wyrażenie niepełne, które jest wyrażeniem eliptycznym, ponieważ mimo że je rozumiemy, to brakuje w nim pewnych składników. Z kolei gdy napotkamy wyrażenie „Ludzie są fajtłapami” i nie potrafimy go zrozumieć, stwierdzamy, że nie ma ono sensu. Zastanawiamy się, dlaczego tak jest, i odkrywamy, że przyczyną jest brak istotnego składnika, a zatem musi to być niedopowiedzenie.

Każdorazowo przed analizą syntaktyczną musielibyśmy przeprowadzić mniej więcej następujące rozumowanie:

1. $\quad$ Czy to wyrażenie jest sensowne, czy nie?

2. Jeżeli jest sensowne, to czy jest wyrażeniem eliptycznym, czy nie?

3. Jeżeli jest bezsensowne, to czy przyczyną tego bezsensu jest obecność niedopowiedzenia, czy też coś innego?

Okazuje się zatem, że nie ma bezpiecznego podejścia bez wcześniejszego określenia sensowności wyrażenia. Nie możemy czysto syntaktycznie wziąć wyrażenia i po prostu analizować go metodą Ajdukiewicza, ponieważ wtedy nie będziemy świadomi tego, czy mamy do czynienia z wyrażeniem niepełnym, i tego, w jaki sposób należy je wypełnić. Istnieje bowiem ryzyko, że 
wpadniemy na przykład w złudne wrażenie, jak w przypadku niedopowiedzeń, że mamy wyrażenie sensowne, kiedy de facto jest ono bezsensowne.

Można by oczywiście spróbować obronić metodę przed zarzutem błędnego koła, postulując, że mamy tutaj do czynienia z hipotezą, którą weryfikujemy przez analizę syntaktyczną. Byłaby to jednak bardzo nieprzekonująca obrona. Istnieje zasadnicza różnica między hipotezą a wiedzą konieczną, żeby w ogóle przeprowadzić analizę. Hipotezę dopiero mamy sprawdzić. My jednak nie stawiamy tylko hipotezy, że wyrażenie jest sensowne albo bezsensowne. Zresztą, gdyby to była tylko hipoteza, to w niczym by nam to nie pomogło. Przypomnijmy sobie na przykład niedopowiedzenia. Jeżeli potraktujemy stwierdzenie, że wyrażenie „Ludzie są beznadziejni” jest bezsensowne, jako hipotezę, a analizę syntaktyczną potraktujemy jako metodę sprawdzania prawdziwości hipotezy, to otrzymamy wynik, że hipoteza była błędna i wyrażenie jest sensowne. To nie może zatem być tylko hipoteza. Musimy to już wiedzieć, inaczej pozostaniemy w błędzie.

\section{PODSUMOWANIE}

Wykazałem, że analiza nie może z czysto syntaktycznego poziomu rozstrzygać o sensowności żadnych wyrażeń języka naturalnego. Różne przykłady wyrażeń niepełnych posłużyły mi, aby wykazać, że każdorazowo, gdy chcemy zastosować analizę syntaktyczną, musimy wpierw z góry już wiedzieć, czy wyrażenie jest sensowne. W obliczu tego, że w języku wyrażenia niepełne występują nagminnie i nie są tylko pewnymi wyjątkami, wydaje się, że głównego celu analizy syntaktycznej nie da się uratować.

\section{BIBLIOGRAFIA}

Ajdukiewicz K. (1935), Die syntaktische Konnextität, „Studia Philosophica” 1, 1-27.

Ajdukiewicz K. (1993), Kategorie syntaktyczne i antynomie logiczne, „Filozofia Nauki” 1(1) [1], 163-182.

Ajdukiewicz K. (1965), Logika pragmatyczna, Warszawa: Państwowe Wydawnictwo Naukowe.

Ajdukiewicz K. (1985a), O spójności syntaktycznej [w:] Język i poznanie. Wybór pism z lat 1920-1939, t. I, Warszawa: Państwowe Wydawnictwo Naukowe, 222-242.

Ajdukiewicz K. (1985b), Pewna metoda eliminacji intensjonalnych zdań i formul zdaniowych [w:] Język i poznanie. Wybór pism z lat 1945-1963, t. II, Warszawa: Państwowe Wydawnictwo Naukowe, 365-370. 
Chybińska A. (2015), Problematyka defektów semiotycznych w ujęciu Kazimierza Ajdukiewicza, „Filo-Sofija” 15(28), 203-219.

Grochowski M. (1976), O pojęciu elipsy, „Pamiętnik Literacki” 67(1), 121-136.

Kopaliński W. (2007), Stownik wyrazów obcych i zwrotów obcojęzycznych z almanachem, Warszawa: Oficyna Wydawnicza RYTM.

Pelc J. (1971), O użyciu wyrażeń, Wrocław: Państwowa Akademia Nauk.

Tałasiewicz M. (2001), Analiza semantyczno-kategorialna. Badanie gramatyczności, czy ustalanie sensu, „Filozofia Nauki” 9(1) [33], 53-75. 